\title{
DETEKSI MANAJEMEN LABA MELALUI PERBEDAAN NILAI ABSOLUT AKRUAL DISKRESIONER SEPUTAR SEASONED EQUITY OFFERINGS
}

\author{
Djaja Perdana \\ Akademi Akuntansi YKPN Yogyakarta, Indonesia \\ Email:djaja_perdana@aaykpn.ac.id
}

\begin{abstract}
Abstrak: Deteksi Manajemen Laba Melalui Perbedaan Nilai Absolut Akrual Diskresioner Seputar Seasoned Equity Offerings. Penelitian ini bertujuan mendeteksi praktik manajemen laba pada perusahaan yang melakukan aksi Seasoned Equity Offerings. Pendeteksian manajemen laba dilakukan melalui pengujian perbedaan nilai absolut akrual diskresioner sebelum dan sesudah aksi Seasoned Equity Offerings (SEO). Penelitian ini melibatkan total 201 data observasi dari 67 sampel perusahaan yang terdaftar di Bursa Efek Indonesia yang melakukan Seasoned Equity Offerings selama periode 2008-2013 dan dipilih melalui metode purposive random sampling serta menggunakan data Laporan Keuangan periode 2004-2016. Pengujian hipotesis menggunakan Wilcoxon Signed Rank Test. Penelitian ini menunjukkan bahwa terdapat perbedaan yang signifikan nilai absolut akrual diskresioner dalam informasi laba perusahaan antara sebelum dengan sesudah melakukan Seasoned Equity Offerings. Nilai absolut akrual diskresioner sebelum Seasoned Equity Offerings lebih besar dibandingkan dengan sesudah Seasoned Equity Offerings. Hal ini menunjukkan terjadinya praktik manajemen laba sebagai dampak asimetri informasi antara manajemen perusahaan dengan investor.
\end{abstract}

Kata kunci: Asimetri informasi, Manajemen Laba, Nilai Absolut Akrual Diskresioner, Seasoned Equity Offerings

\begin{abstract}
Detecting Earning Managemeng by Examining the Changes in Absolute Value of Discretionary Accrual in Relation to Seasoned Equity Offerings. This study aims to detect earnings management practices in companies that perform Seasoned Equity Offerings. Earnings management is detected by examining the change of absolute value of discretionary accrual before and after Seasoned Equity Offerings (SEO). This study utilises 201 observation data from 67 IDX-listed companies which conducted Seasoned Equity Offerings during 2008-2013. The samples were selected by purposive random sampling method and using the data from Financial Report 20042016 period. The test was performed by using Wilcoxon Signed Rank Test. This study found the absolute value of discretionary accruals before Seasoned Equity Offerings is greater than after Seasoned Equity Offerings. These earnings management practices as impact of information asymmetry between management and investors.
\end{abstract}

Keywords: Information Asymmetry, Absolute Value of Discretionary Accruals, Earnings Management, Seasoned Equity Offerings

\section{PENDAHULUAN}

Bagi sebagian besar investor, Seasoned Equity Offerings (SEO) merupakan aksi korporasi yang perlu dicermati sebelum memberi respon karena aksi Seasoned Equity Offerings dapat dijadikan sebagai momentum bagi manajemen untuk mengambil keuntungan dari respon investor. Di sisi lain, investor khawatir salah menentukan respon terhadap aksi Seasoned Equity Offerings (SEO) tersebut, mengingat investor tidak memiliki informasi yang cukup 
memadai mengenai kondisi keuangan perusahaan yang akan melakukan Seasoned Equity Offerings.

Berbagai penelitian terdahulu yang mengkaji tentang terjadinya praktik manajemen laba seputar Seasoned Equtiy Offerings memberikan hasil yang variatif, sebagian hasil penelitian menyimpulkan bahwa terjadi praktik manajemen laba oleh perusahaan sebelum Seasoned Equity Offerings tetapi sebagian penelitian lainnya tidak berhasil membuktikan terjadinya praktik manajemen laba.

Secara konseptual manajemen perusahaan dapat memanfaatkan asimetri informasi antara manajemen dengan investor untuk melakukan praktik manajemen laba terhadap informasi laba yang dilaporkan sebelum penawaran saham tambahan dilakukan. Praktik manajemen laba tersebut dilakukan dengan cara menaikkan nilai akrual diskresioner, tujuannya adalah untuk menaikkan harga saham tambahan yang ditawarkan oleh perusahaan pada saat Seasoned Equity Offerings (Teoh et al., 1998).

Kendala dihadapi oleh penelitian terdahulu di dalam membuktikan praktik manajemen laba salah satunya adalah disebabkan oleh keterbatasan data laporan keuangan perusahaan yang tersedia baik sebelum maupun sesudah Seasoned Equity Offerings, sehingga sampel yang dapat digunakan dalam penelitian seringkali berjumlah relatif sedikit dengan rentang periode pelaporan keuangan yang relatif pendek. Selain itu, pemanfaatan nilai akrual diskresioner di dalam praktik manajemen laba cenderung sulit dideteksi oleh investor (Teoh et al., 1998).
Oleh karena itu, penelitian kali ini berupaya untuk mendeteksi terjadinya praktik manajemen laba oleh perusahanperusahaan yang melakukan aksi Seasoned Equity Offerings dengan melibatkan sampel yang lebih banyak dari periode pelaporan yang lebih panjang. Penelitian ini akan mendeteksi praktik manajemen laba di dalam laporan keuangan yang dikeluarkan oleh perusahaan sebelum dan sesudah aksi Seasoned Equity Offerings (SEO) melalui perbedaan nilai absolut akrual diskresioner.

Diharapkan hasil penelitian ini memberikan informasi yang dapat membantu investor dalam mengambil keputusan investasi terhadap perusahaan yang berencana akan melakukan aksi Seasoned Equity Offerings. Di sisi lain hasil penelitian ini diharapkan dapat memperkuat hasil-hasil penelitian terdahulu dan teoriteori yang terkait. Pertanyaan yang diajukan dalam penelitian ini adalah; apakah terdapat perbedaan nilai absolut akrual diskresioner di dalam informasi laba yang disampaikan oleh perusahaan di periode pelaporan keuangan sebelum dan sesudah melakukan aksi Seasoned Equity Offerings (SEO)?

Penelitian yang pernah dilakukan oleh Cohen dan Zarowin (2008) mendapatkan bukti bahwa perusahaan yang melakukan Seasoned Equity Offerings cenderung outperform di periode-periode sebelum Seasoned Equity Offerings kemudian underperform di periode-periode sesudah Seasoned Equity Offerings apabila dibandingkan dengan perusahaanperusahaan lain di dalam satu kelompok industri.

Seasoned Equity Offerings (SEO) atau disebut juga dengan seasoned new issues 
merupakan penawaran saham tambahan yang dilakukan perusahaan yang terdaftar di pasar modal, di luar saham yang terlebih dahulu telah ditawarkan pada masyarakat investor melalui IPO (Initial Public Offerings).

Seasoned Equity Offerings dapat dilakukan dalam bentuk-bentuk penawaran seperti; right issues yaitu kegiatan penawaran umum terbatas kepada pemegang saham lama dalam rangka penerbitan hak memesan saham terlebih dahulu. Saham ditawarkan kepada pemegang saham lama dengan harga tertentu. Kedua additional offerings yaitu saham ditawarkan kepada setiap investor baru atau lama yang ingin membeli. Additional offerings terbagi ke dalam dua bentuk yaitu partial listing dan company listing. Partial listing adalah pencatatan sebagian (partial) saham perusahaan atau pemegang saham lama di bursa sehingga dapat diperdagangkan di pasar sekunder. Partial listing ini dapat dilakukan beberapa kali. Company listing adalah pencatatan semua saham milik perusahan atau pemegang saham lama di bursa sehingga dapat diperdagangkan di pasar sekunder.

Sama halnya dengan Initial Public Offerings (IPO), Seasoned Equity Offerings (SEO) juga berulang kali menjadi objek penelitian terdahulu karena diduga mengandung unsur praktik manipulasi laba yang dilakukan oleh perusahaan seputar Seasoned Equity Offerings (SEO). Praktik manipulasi laba ini seringkali disebut dengan istilah manajemen laba.

Menurut Scott (2015), manajemen laba merupakan intervensi manajemen dalam proses penyusunan laporan keuangan untuk pihak eksternal, intervensi tersebut berupa kebijakan meratakan, menaikan, atau menurunkan pelaporan laba. Manajemen dapat memanfaatkan kelonggaran di dalam penggunaan metode akuntansi, dan membuat kebijakan-kebijakan (discretionary) yang dapat mempercepat pengakuan pendapatan atau menunda pengakuan biaya, agar laba perusahaan yang dilaporkan menjadi lebih kecil atau lebih besar sesuai dengan yang diharapkan.

Menurut Healy dan Wahlen (1999) ada tiga motivasi yang mendorong terjadinya praktik manajemen laba oleh perusahaan, yaitu (1) motivasi pasar modal (capital market motivations), (2). motivasi kontrak (contracting motivation) dan (3) motivasi peraturan (regulatory motivations).

Sedangkan menurut Scott (2015), faktorfaktor yang mendorong manajer melakukan manajemen laba adalah (1) rencana bonus (Bonus scheme), (2) kontrak utang jangka panjang (debt covenant), (3) motivasi politik (political motivation), (3) motivasi perpajakan (taxation motivation), (4) pergantian CEO (Chief Executive Officer), (5) penawaran saham perdana (Initial Public Offering).

Manajemen laba dapat dideteksi dengan menggunakan beberapa model perhitungan, salah satunya adalah Modified Jones Model yang mengukur nilai akrual diskresioner yang diproksikan dalam bentuk nilai error term dari persamaan regresi total akrual. Akrual diskresioner merupakan kebijakan akuntansi yang memberikan keleluasaan pada manajemen untuk menentukan jumlah transaksi akrual secara fleksibel. Manajemen memanipulasi laba yang dilaporkan dengan memanfaatkan transaksi akrual diskresioner. Tujuan dari pemanfaatan akrual diskresioner 
ini oleh manajemen adalah untuk menaikkan harga saham yang ditawarkan saat Seasoned Equity Offerings (Teoh et al., 1998).

Dalam penelitian ini, nilai absolut akrual diskresioner digunakan untuk mengukur besaran manajemen laba yang diproksikan dalam nilai akrual diskresioner dari posisi angka nol tanpa mengindahkan tanda positif atau negatif yang menyertai. Akrual diskresioner negatif dan akrual diskresioner positif diasumsikan memiliki besaran (magnitude) yang sama apabila diukur jaraknya dari angka nol. Nilai absolut akrual diskresioner merupakan proksi dan ukuran balikan (inverse measure) kualitas informasi akuntansi. Semakin tinggi nilai absolut akrual diskresioner berarti semakin rendah kualitas informasi akuntansi. Nilai absolut juga dapat digunakan untuk mengetahui indeks perbandingan akrual diskresioner sebelum dan sesudah Seasoned Equity Offerings.

Secara matematis, angka absolut merupakan besaran (magnitude) aktual dari suatu nilai atau ukuran tanpa mengindahkan tanda (negatif atau positif) yang dimiliki angka tersebut. Pada prinsipnya nilai absolut digunakan untuk mengetahui seberapa jauh jarak suatu angka dari posisi angka nol. Angka akrual diskresioner negatif mempunyai nilai besaran aktual yang sama dengan angka akrual diskresioner positif, keduanya berkaitan erat dengan kinerja laba yang diperoleh perusahaan.

Kasznik (1999) membuktikan adanya korelasi antara kinerja laba perusahaan dengan akrual diskresioner. Perusahaan dengan pendapatan rendah cenderung menunjukkan akrual diskresioner negatif. Sebaliknya, perusahaan yang memiliki pendapatan tinggi cenderung menunjukkan akrual diskresioner positif. Tampaknya hal ini terjadi karena perusahaan dengan pendapatan tinggi atau rendah yang bersifat abnormal memiliki efek positif atau negatif terhadap laba yang mencakup komponen akrual.

Grand theory yang digunakan dalam penelitian ini adalah Agency theory, seperti yang digambarkan dalam Gambar 1. Morris (1987) menyatakan bahwa fenomena yang terjadi seputar Seasoned Equity Offerings dengan menggunakan agency theory. Teori ini mendeskripsikan masalah yang muncul antara principal dengan agent dalam pemisahan kepemilikan dan kontrol terhadap perusahaan, manajemen perusahaan berusaha untuk memberikan kesan positif kepada investor tentang perusahaan yang dikelolanya. Kesan positif ini diwujudkan dalam bentuk kinerja keuangan yang dilaporkannya. Namun kesan positif ini dalam jangka panjang tidak dapat dipertahankan oleh manajemen, yang tercermin dari penurunan kinerja keuangan yang dilaporkan oleh perusahaan tersebut pada periode sesudahnya (Teoh et al., 1998).

Praktik ini dapat terjadi karena adanya asimetri informasi antara investor dengan manajemen perusahaan. Information asymmetry atau asimetri informasi merupakan informasi privat yang hanya dimiliki oleh manajemen dan sejumlah investor tertentu saja yang mendapat informasi (Jogiyanto, 1998). Walaupun investor mempunyai informasi yang cukup memadai mengenai perusahaan yang melakukan Seasoned Equity Offerings, asimetri informasi tetap terjadi dalam penawaran tersebut (Guo dan Mech, 2000). Kondisi inilah yang memotivasi manajemen 


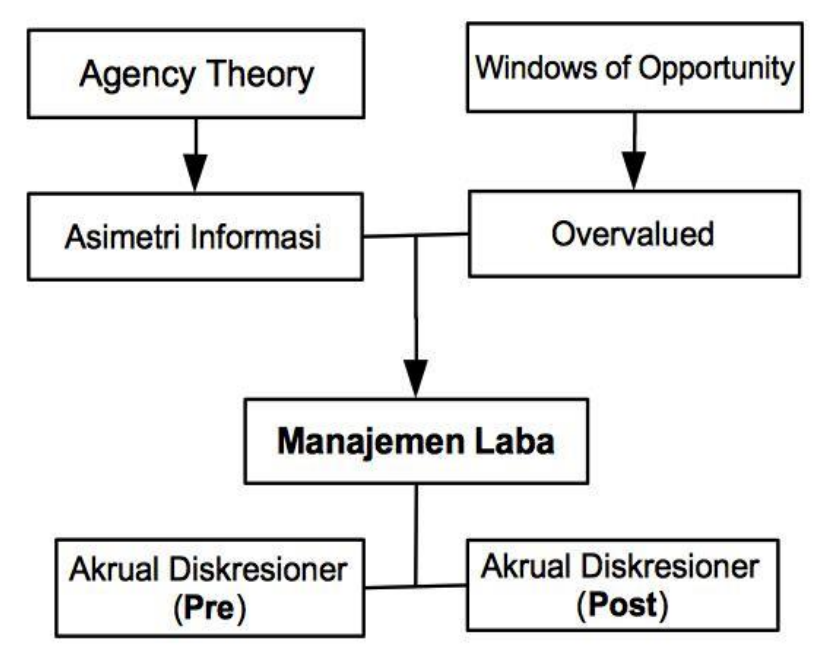

Gambar 1. Kerangka Konseptual Penelitian

untuk bersikap oportunistik dengan memanipulasi kinerjanya, baik sebelum dan pada saat penawaran saham (Rangan, 1998; Teoh et al., 1998). Manipulasi yang dikenal dengan istilah manajemen laba ini dalam jangka waktu tertentu akan menunjukkan penurunan kinerja (underperformance) setelah penawaran (McLaughlin, Safieddine, \& Vasuvedan, 1996; Loughran dan Ritter, 1997; Teoh et al., 1998; Rangan, 1998).

Sama halnya saat IPO, asimetri informasi terjadi juga saat Seasoned Equity Offerings, manajemen mengetahui lebih banyak kondisi perusahaan dibandingkan investor (Guo dan Mech, 2000). Kim dan Park (2005) menemukan bahwa perusahaan yang akan melakukan Seasoned Equity Offerings membuat keputusan akuntansi yang oportunistik untuk menerbitkan saham baru di saat harganya mendatar. Manajemen memanfaatkan asimetri informasi ini untuk melakukan manajemen laba terhadap informasi laba yang dilaporkan sebelum penawaran saham dilakukan. Manajemen laba dilakukan dengan menaikkan nilai akrual diskresioner (Teoh et al., 1998). Teoh et al. (1998) membuktikan bahwa asimetri informasi membuat prospektus penawaran saham sebelum Seasoned Equity Offerings mudah untuk dimanipulasi. Hubungan antara manajemen laba dengan akrual diskresioner seputar Seasoned Equity Offerings dapat digambarkan dalam kerangka konseptual penelitian ini di Gambar 1.

Insentif atau sikap opportunistik juga menjadi faktor esensial yang melandasi terjadinya manajemen laba (Schipper, 1989; Healy dan Wahlen, 1998). Rangan (1998) mendokumentasikan hasil penelitian yang membuktikan bahwa terjadi akrual abnormal seputar Seasoned Equity Offerings. DuCharme, Malatesta, \& Sefcik (2004) membuktikan bahwa akrual secara abnormal mengalami peningkatan pada perusahaan yang akan melakukan Seasoned Equity Offerings.

Rangan (1998) menemukan bukti terjadinya abnormal akrual positif saat laba yang dilaporkan meningkat pada sebagian besar perusahaan di seputar Seasoned Equity Offerings. Rangan (1998) menginterpretasikan temuannya dengan menyatakan bahwa perusahaan mengatur labanya meningkat sebelum Seasoned Equity Offerings sehingga 
pasar saham mengalami misleading oleh peningkatan laba yang dilaporkan tersebut, sehingga secara temporer penerbitan saham tambahan mengalami overvalued dan investor kecewa setelah mengetahui laba yang diperoleh perusahaan setelah Seasoned Equity Offerings mengalami penurunan dan akhirnya harga saham jatuh.

Teoh et al. (1998) menginvestigasi pengaruh Seasoned Equity Offerings terhadap laba yang dilaporkan perusahaan melalui perubahan nilai akrual diskresioner. Mereka menemukan bukti bahwa perusahaan melakukan penyesuaian akrual diskresioner sehingga nilai laba bersih yang dilaporkan lebih tinggi sebelum Seasoned Equity Offerings dibanding sesudah Seasoned Equity Offerings. Sedangkan Roychowdhury (2006) menemukan bukti bahwa perusahaan menggunakan alat manajemen laba ganda dengan tujuan untuk mendapatkan ukuran laporan keuangan tertentu dan menghindari nilai rugi pada laporan tahunan.

Namun salah satu penelitian di Indonesia yang pernah dilakukan Hakim (2008) tidak menemukan adanya perbedaan nilai akrual diskresioner sebelum dan sesudah Seasoned Equity Offerings pada laporan keuangan perusahaan. Penelitian tersebut menggunakan sampel dari 22 perusahaan yang melakukan Seasoned Equity Offerings selama periode 2000-2003. Sedangkan hasil penelitian Gumanti (2000), dan Sutanto (2000) yang mencoba membuktikan terjadinya manajemen laba selama dua tahun sebelum perusahaan melakukan penawaran saham menunjukkan hasil terjadinya penurunan laba yang dilaporkan setelah penawaran. Namun
Gumanti (2000) dan Sutanto (2000) menguji manajemen laba pada aksi IPO.

Oleh karena itu, untuk menguji kembali dugaan terjadinya manajemen laba yang dilakukan perusahaan yang melakukan Seasoned Equity Offerings maka penelitian ini mengajukan hipotesis sebagai berikut:

H1: Terdapat perbedaan nilai absolut akrual diskresioner yang terkandung dalam informasi laba perusahaan sebelum dan sesudah melakukan Seasoned Equity Offerings.

\section{METODE}

Penelitian ini menggunakan data observasi sebanyak 201 dari 67 sampel perusahaan yang terdaftar di Bursa Efek Indonesia yang melakukan Seasoned Equity Offerings selama periode tahun 2008-2013 dan menggunakan data laporan keuangan periode 2004-2016 (4 periode sebelum, 1 periode saat Seasoned Equity Offerings dan 3 periode sesudah Seasoned Equity Offerings).

Sampel diambil dengan teknik purposive random sampling untuk mendapatkan sampel yang sesuai dengan kriteria yaitu; (1). perusahaan yang melakukan Seasoned Equity Offerings paling cepat 5 tahun setelah IPO. (2). aksi Seasoned Equity Offerings yang dilakukan oleh perusahaan merupakan aksi Seasoned Equity Offerings yang pertama kali dilakukan oleh perusahaan tersebut. (3). selama rentang 3 tahun sebelum dan 3 tahun setelah Seasoned Equity Offerings, perusahaan tidak melakukan aksi korporasi yang serupa. (4). tersedianya Laporan Keuangan yang dikeluarkan oleh perusahaan selama rentang 4 periode sebelum Seasoned Equity Offerings, saat Seasoned Equity 
Offerings dan 3 periode setelah Seasoned Equity Offerings.

Penelitian ini menggunakan Modified Jones Model (Dechow, Sloan, dan Sweeney, 1995) untuk mendapatkan nilai akrual diskresioner yang merupakan proksi praktik manajemen laba. Perhitungan diawali dengan persamaan (1) berikut ini:

\section{T. Accr $_{i t}=$ Net Income $_{i t}-$ OCF $_{i t}$}

\section{Keterangan:}

T. Accrit = Total akrual perusahaan i pada periode ke-t

Net Incomeit = Laba bersih perusahaan i pada periode ke - $t$

OCFit = Arus kas operasional perusahaan i periode ke-t

Selanjutnya hubungan antara variabel Total Accrual dengan Discretionary Accrual diformulasikan dalam persamaan (2) berikut ini.

\section{T. $A_{c c r}{ }_{i t}=$ Non $D A_{i t}+D A_{i t}$}

Keterangan:

T. Accrit $=$ Total Akrual perusahaan i pada periode ke-t

Non D.Ait = Nilai Non-Discretionary Accrual perusahaan i pada periode ke-t

D. Ait = Nilai Discreationary Accrual perusahaan i pada periode ke-t

Dalam Modified Jones Model persamaan (2) di atas diekstrak ke dalam persamaan (3) berikut ini:

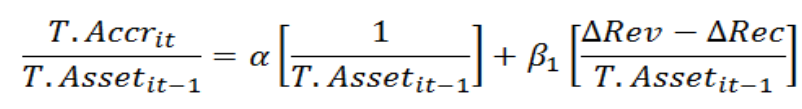

$$
+\beta_{2}\left[\frac{G P P E}{\text { T.Asset }_{i t-1}}\right]+\varepsilon_{i t}
$$

Keterangan:

T.Accr : Total Accrual
A
: Nilai Konstanta
B
: Nilai Koefisien Beta

$\Delta$ Rev : Perubahan jumlah pendapatan

$\Delta \operatorname{Rec}:$ Perubahan jumlah piutang dagang

GPPE : Aset Tetap Kotor

T.Assetit-1 : Total Aset tahun ke t-1

घi : Error term

Sehingga nilai non-discretionary accrual (Non-DA) dan discretionary accrual (DA) dapat dihitung dengan persamaan (4) dan (5) berikut ini:

$$
\begin{aligned}
& \text { Non D. } A_{i t}=\alpha\left(\frac{1}{\text { T. Asset }_{i t-1}}\right)+\beta_{1}\left(\frac{\Delta \operatorname{Rev}-\Delta \operatorname{Rec}}{\text { T. }_{\text {Asset }} \text { it }-1}\right) \\
& +\beta_{2}\left(\frac{G P P E}{\text { T. Asset }_{i t-1}}\right)+\varepsilon_{i t}
\end{aligned}
$$

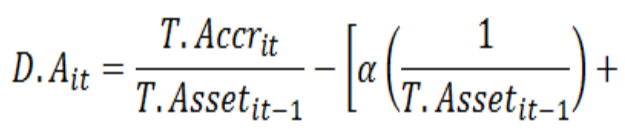

$$
\begin{aligned}
& \left.\beta_{1}\left(\frac{\Delta \operatorname{Rev}-\Delta \operatorname{Rec}}{\text { T. Asset }_{i t-1}}\right)+\beta_{2}\left(\frac{G P P E}{{\text { T. } \text { Asset }_{i t-1}}_{1}}\right)\right]
\end{aligned}
$$

Hasil perhitungan akrual diskresioner tersebut kemudian diabsolutkan untuk membentuk variabel ABSDA (Absolute Discretionary Accrual) dan selisih nilai (Difference) ABSDA_Sebelum dengan ABSDA_Sesudah diuji normalitasnya menggunakan Kolmogorov-Smirnov dan Shapiro-Wilk, sedangkan uji beda menggunakan Wilcoxon Signed Rank Test.

\section{HASIL DAN PEMBAHASAN}

Penghitungan nilai absolut akrual diskresioner (ABSDA) sebelum dan sesudah SEO yang merupakan nilai absolut residu dari model regresi linier berganda yang mendasarkan pada persamaan (5), diperoleh hasil sebagaimana yang dijabarkan pada Tabel 1. 
Tabel 1. Statistik Deskriptif ABSDA Sebelum, Sesudah, dan Selisih

\begin{tabular}{lccc}
\hline Statistik & ABSDA_Sebelum & ABSDA_Sesudah & Diff_ABSDA \\
\hline Rata-rata & 0.307 & 0.125 & 0.182 \\
Median & 0.144 & 0.071 & 0.064 \\
SD & 1.495 & 0.212 & 1.517 \\
Minimum & 0.000 & 0.000 & -2.510 \\
Maximum & 21.170 & 2.530 & 21.150 \\
Skewness & 13.736 & 7.840 & 13.306 \\
Kurtosis & 192.474 & 83.284 & 184.944 \\
\hline
\end{tabular}

Seperti yang terlihat dalam Tabel 1 , data ABSDA_Sebelum memiliki angka mean= 0.3067 , median $=0.1435$ dengan standar deviasi $=1.49484$, sedangkan data ABSDA_Sesudah memiliki angka mean= 0.1246, dan median $=0.0706$ sedangkan standar deviasi $=0.21193$. Selanjutnya penelitian ini menghitung nilai selisih (Difference) ABDA_Sebelum dengan ABSDA_Sesudah untuk digunakan sebagai tambahan data pengujian normalitas. Statistik deskriptif nilai selisih (Difference) ABSDA ditunjukkan dalam Tabel 1, sedangkan hasil uji normalitas nilai ABSDA ditunjukkan dalam Tabel 2.

Berdasarkan hasil uji normalitas di atas dapat diketahui bahwa data observasi tidak berdistribusi normal maka untuk selanjutnya penelitian ini menggunakan pendekatan non-parametrik untuk menguji komparasi data sebelum dan sesudah dengan memanfaatkan Wilcoxon Signed Rank Test. Tabel 3
Pada Tabel 3, diketahui bahwa pengujian taraf signifikansi perbedaan nilai absolut akrual diskresioner (Absolute Discretionary Accrual atau ABSDA) sebelum dan sesudah Seasoned Equity Offerings memperoleh hasil nilai $Z=-6.312$ dengan asymptotic significance $(2$-tailed $)=0.000$ atau $<0.05$ maka dapat disimpulkan bahwa terdapat perbedaan nilai absolut diskresioner sebelum dengan sesudah Seasoned Equity Offerings, sehingga $\mathrm{H} 1$ diterima. Dalam Tabel (5) juga diketahui bahwa sebanyak 139 $(69,15 \%)$ data observasi ABSDA_Sesudah Seasoned Equity Offerings lebih kecil dibandingkan dengan ABSDA_Sebelum Seasoned Equity Offerings. Sedangkan 62 (30,85\%) ABSDA_Sesudah Seasoned Equity Offerings lebih besar dibandingkan dengan ABSDA_Sebelum Seasoned Equity Offerings.

Penghitungan indeks nilai absolut akrual diskresioner (ABSDA) sebelum dan sesudah Seasoned Equity Offerings (SEO) dilakukan

Tabel 2. Uji Normalitas

\begin{tabular}{lcccccc}
\hline & \multicolumn{3}{c}{ Kolmogrov-Smirnov } & \multicolumn{3}{c}{ Shapiro-Wilk } \\
\cline { 2 - 7 } & Statistic & df & Sig. & Statistic & df & Sig. \\
\hline ABSDA_Sebelum & .419 & 201 & .000 & .103 & 201 & .000 \\
ABSDA_Sesudah & .278 & 201 & .000 & .428 & 201 & .000 \\
Diff_ABSDA & .390 & 201 & .000 & .132 & 201 & .000 \\
\hline
\end{tabular}


Tabel 3. Wilcoson Signed Ranks Text

\begin{tabular}{llrrr}
\hline & N & Mean Rank & Sum of Ranks \\
\hline ABSDA_Sesudah- Negative Ranks & 139 & 110.52 & 15362.00 \\
ABSDA_Sebelum & Positive Ranks & 62 & 79.66 & 4939.00 \\
& Ties & 0 & & \\
& Total & 201 & & \\
\hline Z & -6.312 & & \\
& Asymp. Sig (2-tailed) & .000 & \\
\hline
\end{tabular}

dengan menggunakan metode agregatif sederhana yang terlihat dalam persamaan (6). Hasil perhitungan indeks tersebut memperoleh hasil sebagai berikut:

$$
\begin{aligned}
\text { Index } A B S D A & =\frac{\sum A B S D A_{\text {Sesucth }}}{\sum A B S D A_{\text {Sebelion }}} \times 100 \\
& =\frac{25.03}{61.56} \times 100=\mathbf{4 0 , 6 6}
\end{aligned}
$$

Berdasarkan hasil tersebut maka dapat disimpulkan bahwa nilai absolut akrual diskresioner (ABSDA) sesudah Seasoned Equity Offerings lebih rendah dibandingkan sebelum Seasoned Equity Offerings yaitu sebesar 40,66\%. Dengan kata lain, nilai absolut akrual diskresioner (ABSDA) sebelum Seasoned Equity Offerings lebih tinggi 59.34\% dibandingkan sesudah Seasoned Equity Offerings. Angka indeks di atas mempertajam hasil pendeteksian praktik manajemen laba yang dilakukan melalui peningkatan nilai akrual diskresioner sebelum aksi Seasoned Equity Offerings. Besaran selisih nilai akrual diskresioner sebelum Seasoned Equity Offerings yang hampir mencapai $60 \%$ dibandingkan dengan sesudah Seasoned Equity Offerings menunjukkan upaya besar manajemen untuk terlihat outperform di mata investor sebelum menawarkan saham tambahan melalui
Seasoned Equity Offerings, namun kemudian underperform sesudah Seasoned Equity offerings.

Hasil penelitian ini mengkonfirmasi riset sebelumnya yang dilakukan oleh Cohen dan Zarowin (2008) yang membuktikan bahwa perusahaan-perusahaan yang melakukan Seasoned Equity Offerings cenderung outperform di periode sebelum Seasoned Equity Offerings namun kemudian underperform di periode-periode sesudah Seasoned Equity Offerings. Kinerja perusahaan yang terkesan outperform tersebut merupakan efek dari praktik manajemen laba yang dilakukan perusahaan melalui pemanfaatan asimetri informasi antara manajemen dengan investor. Praktik manajemen laba tersebut dilakukan dengan cara menaikkan nilai akrual diskresioner, tujuannya adalah untuk mendapatkan respon yang baik dari investor pada saat penawaran saham tambahan dilakukan.

Perusahaan yang melakukan Seasoned Equity Offerings membuat keputusan akuntansi yang oportunistik sebelum penawaran dilakukan. Sikap oportunistik ini merupakan faktor esensial yang melandasi terjadinya manajemen laba. Hal ini sesuai dengan hasil penelitian Schipper (1989), Healy dan Wahlen (1998). 
Hasil penelitian ini juga memberikan bukti empiris bahwa penggunaan angka absolut terhadap nilai akrual diskresioner mampu memperkuat kemampuan perangkat analisis dalam mendeteksi praktik manajemen laba. Angka absolut dapat mengukur besaran (magnitude) manajemen laba yang diproksikan dengan nilai akrual diskresioner dari posisi angka nol tanpa mengindahkan simbol positif atau negatif yang menyertai angka tersebut. Akrual diskresioner negatif dan positif diasumsikan memiliki besaran yang sama apabila diukur jaraknya dari angka nol. Angka akrual diskresioner negatif mempunyai nilai besaran aktual yang sama dengan angka akrual diskresioner positif, keduanya berkaitan erat dengan kinerja laba yang dilaporkan perusahaan.

Hal ini sesuai dengan hasil penelitian Kasznik (1999) yang membuktikan adanya korelasi antara kinerja laba perusahaan dengan akrual diskresioner. Perusahaan dengan pendapatan rendah cenderung menunjukkan akrual diskresioner negatif. Sebaliknya, perusahaan yang memiliki pendapatan tinggi cenderung menunjukkan akrual diskresioner positif. Pendapatan perusahaan yang bersifat abnormal memiliki efek positif atau negatif terhadap laba termasuk terhadap komponen akrual.

Penggunaan angka absolut dalam penelitian ini sekaligus menjadi pembeda penelitian ini dibandingkan dengan penelitian yang pernah dilakukan oleh Hakim (2008) yang menggunakan angka relatif akrual diskresioner untuk mendeteksi praktik manajemen laba pada perusahaanperusahaan di Indonesia yang melakukan Seasoned Equity Offerings.

\section{SIMPULAN}

Hasil penelitian ini membuktikan bahwa terdapat perbedaan nilai absolut akrual diskresioner di dalam informasi laba yang dilaporkan oleh perusahaan sebelum dan sesudah Seasoned Equity Offerings (SEO). Nilai absolut akrual diskresioner sebelum Seasoned Equity Offerings lebih tinggi dibandingkan dengan nilai absolut akrual diskresioner sesudah Seasoned Equity Offerings. Hasil ini menunjukkan bahwa terjadi praktik manajemen laba yang dilakukan oleh perusahaan sebelum Seasoned Equity Offerings.

Implikasi teoritis dari hasil penelitian ini berupa penguatan teori windows of opportunity, agency theory dan asimetri informasi dalam pengkajian praktik manajemen laba perusahaan sebelum dan sesudah melakukan aksi Seasoned Equity Offerings. Penguasaan informasi yang tidak seimbang mengenai kondisi keuangan perusahaan mendorong manajemen untuk melakukan praktik manajemen laba dengan tujuan memunculkan kesan positif investor terhadap kinerja perusahaan sebelum melakukan penawaran saham tambahan. Sedangkan implikasi secara praktis, hasil penelitian ini dapat diperhitungkan oleh investor sebelum mengambil keputusan investasi dan merespon aksi penawaran saham tambahan yang dilakukan oleh perusahaan.

Keterbatasan dari penelitian ini adalah pengujian yang dilakukan hanya menggunakan satu model saja yaitu Modified Jones Model sehingga komparasi hasil masih dapat dikaji lebih lanjut. Oleh karena itu, untuk penelitian selanjutnya dapat 
melibatkan sejumlah model lain dengan tujuan dapat semakin memperkuat hasil yang diperoleh. Kemudian pengujian terhadap variabel absolut akrual diskresioner masih perlu dikembangkan dengan melibatkan variabel-variabel lain seperti Return Turn Over Ratio dan Working Capital Ratio dengan tujuan untuk mengetahui korelasi di antara variabel-variabel tersebut.

\section{DAFTAR PUSTAKA}

Cohen, D.A. \& Zarowin, P. (2008) AccrualBased and Real Earnings Management Activities Around Seasoned Equity Offerings. Diakses dari SSRN: https://ssrn.com/abstract=1081939 atau http://dx.doi.org/10.2139/ssrn.1081939.

Dechow, P.M., Sloan, R.G., \& Sweeney, A.P. (1995). Detecting Earnings Management. The Accounting Review, 70(2), 193-225.

DuCharme, L., Malatesta, P.H., \& Sefcik, S.E. (2004). Earnings Management, Stock Issues and Shareholder Lawsuit. Journal of Financial Economics, 71(1), 27-49.

Gumanti, T.A. (2000). Earnings Management dalam Penawaran Saham Perdana di Bursa Efek Jakarta. Jurnal Riset Akuntansi Indonesia, 4(2), 165-183.

Guo, L., \& Mech, T.S. (2000). Conditional Event Study, Anticipation and Asymmetric Information: The Case of Seasoned Equity Issues and Pre-issue Information Releases. Journal of Empirical Finance, 7(2). Diakses dari https://doi.org/10.1016/S09275398(00)00007-4

Hakim, L. (2008) Analisis Indikasi Earnings Management Terhadap Kinerja pada Seasoned Equity Offerings. Skripsi. Universitas Islam Negeri Syarif Hidayatullah.

Healy, P., \& Wahlen, J.M. (1999). A Review of The Earnings Management Literature and
It's Implication for Standard Setting. Accounting Horizons, 13(4), 365-383.

Jogiyanto. (1998) Teori Portofolio and Analisis Investasi. Yogyakarta: Penerbit BPFE.

Kasznik, R. (1999). On the Association Between Voluntary Disclosure and Earnings Management. Journal of Accounting Research, 37(1), 57-81.

Kim, Y., \& Park, M.S. (2005). Pricing of Seasoned Equity Offers and Earnings Management. Journal of Financial and Quantitative Analysis, 40(2), 435-463.

Loughran, T. \& Ritter, J.R. (1997). The Operating Performance of Firms Conducting Seasoned Equity Offerings. The Journal of Finance, 52(5), 1823-1850.

McLaughlin, R., Safieddine, A., \& Vasudevan, G.K. (1996). The Operating Performance of Seasoned Equity Issuers: Free Cash Flow and Post Issue Performance. Financial Management, 25(4), 41-53.

Morris, R.D. (1987). Signalling Agency Theory and Accounting Policy Choice. Accounting and Business Research, 18(69), 47-56.

Rangan, S. (1998). Earnings Management and The Performance of Seasoned Equity Offerings. Journal of Financial Economics, 50(1), 101-122.

Roychowdhury, S. (2006). Earnings Management Through Real Activities Manipulation. Journal of Accounting and Economic, 42(3), 335-370.

Schipper, K. (1989). Commentary on Earnings Management. Accounting Horizons, 3(4), 91-102.

Scott, W. (2015) Financial Accounting Theory ( $7^{\text {th }}$ Edition). Canada: Pearson Canada Inc.

Sutanto, I.I. (2000). Indikasi Manajemen Laba Menjelang IPO oleh Perusahaanperusahaan yang Terdaftar di Bursa Efek Jakarta. Tesis. Universitas Gadjah Mada. 
Teoh, S.H., Welch, I., \& Wong, T.J. (1998). Earnings management and The Underperformance of Seasoned Equity Offerings. Journal of Financial Economics, 50(1), 63-99.
Teoh, S.H., Wong, T.J., \& Rao, G.R. (1998). Are Accruals During an Initial Public Offering Opportunistic?. Review of Accounting Studies, 3(1-2), 175-208. 